\title{
The Effects of Corporate Governance Mechanisms on Firms Dividend Payout Policy in Nigeria
}

\author{
Uwuigbe Uwalomwa, Olusanmi Olamide and lyoha Francis \\ Department of Accounting, School of Business, College of Development Studies, \\ Covenant University, Ota, Nigeria
}

Correspondence should be addressed to: Alexander K. Buchholz; abuchholz@brooklyn.cuny.edu

Received date: 24 September 2013; Accepted date: 8 January 2014; Published date: 16 February 2015

Copyright (c) 2015. Uwuigbe Uwalomwa, Olusanmi Olamide and lyoha Francis. Distributed under Creative Commons CC-BY 4.0

\begin{abstract}
This article investigates the relationship between corporate governance mechanisms and the dividend payout policies of firms in Nigeria. To achieve the objectives of this study, a total of 50 listed firms were selected and analyzed for the study using the judgmental sampling technique. Also, the annual reports for the period 2006-2011 were used for the study. The paper was basically modeled to examine the effects of board size, ownership structure, CEO duality and board independence on the dividend payout decisions of firms operating in Nigeria using the regression analysis method. Findings from the study revealed that board size, ownership structure, CEO duality and board independence had a significant positive effect on the dividend payout decisions of the sampled firms. The study therefore concludes that greater proportion of independent directors in a firm provides a positive influence on firms' dividend payout decisions with a view to reduce the free cash flow.
\end{abstract}

Keywords: Dividend Payout; Ownership Structure, CEO Duality; Board Independence

\section{Introduction}

One of the main fundamental issues in corporate finance has been the dividend payout decision of firms, which has always been studied in relation to a firm's financing decisions. According to Uwuigbe (2012), dividend policy remains one of the most salient financial decisions not only from the viewpoint of firms, but also from that of the shareholders, consumers, employees and regulatory institutions. It is one of the salient components of firm policies and has been viewed as an interesting issue in the literatures. Firms' decisions related to dividend policy have been a subject of debate in the financial literatures. It remains one of the most controversial topics and researched areas of corporate finance. According to Black (1976), the harder we look at the

Cite this Article as: Uwuigbe Uwalomwa, Olusanmi Olamide and Iyoha Francis (2015), "The Effects of Corporate Governance Mechanisms on Firms Dividend Payout Policy in Nigeria ", Journal of Accounting and Auditing: Research \& Practice, Vol. 2015 (2015), Article ID 313679, DOI: 10.5171/2015.313679 
concept of dividend, the more it seems like a puzzle, with pieces that just do not fit together. Economics and finance researchers have long wondered why firms pay dividends even though cash allotments are less advantageous from a tax perspective than cash retention (Black, 1976).

Dividend policy has been analyzed for many decades, but no universally accepted explanation for companies' observed dividend behavior has been established. Brealey and Myers (2005) described dividend policy as one of the top ten most difficult unsolved problems in financial economics. Dividends as the term implies can be described as the reward for providing finances to a firm. According to Uwuigbe (2012), without any dividend payout, shares would not have any value. Nevertheless, dividend policy in the context of this study, relates to firm's dividend payout policy that an organisation imbibes in deciding the pattern and size of cash distribution to shareholders over time. For firms, it is a key policy around which other financial policies rotate (Alii et al., 1993; Uwuigbe, 2013). Profit distribution decisions remain one of the key decision areas in economic and finance since it tends to ascertain the amount that flows to investors and the amount that is retained by firm for investment (Ross et al., 2002). Thus, Lintner (1956) opined that firms in developed markets target their dividend payout with the help of current earnings and past dividends. In order to reach such target, various modifications are made in the dividend decisions of firms, and hence firms should maintain stable dividend policies. Miller and Modigliani (1961) on the other hand opined that dividend policy decisions were irrelevant in determing the present value of shares considering the illogical assumptions of market perfections, zero transaction costs, perfect certainty and indifferent behaviour of investors. However, Miller and Scholes (1982) argued that in the real world firms' dividend decision is inspired more by high taxes on dividends than capital gains and market imperfections. More so, series of theoretical models and explanations describing the factors that managers of organisations should consider when making dividend policy decisions have been developed by academics and researchers.

Since then, a number of controversial judgments have been advanced to ascertain the factors which affect the dividend policy decisions of firms (Al-Malkawi, 2007; Uwuigbe, 2013). Prior research has attempted to provide answers to questions relating to what should a firm pay as dividend? How does a dividend payout decision affect the appraisal of a firm? Is dividend policy determined dependently or independently? But still, despite the answers provided to these questions, mystery still shrouds the dividend decisions of firms. However, despite the series of literature relating to dividend payout decisions, researchers have not yet reached a consensus about what determines dividend payout ratios. Hence, this study adds to existing literature by empirically examining the effects of corporate governance mechanisms on the dividend payout policy of listed firms in Nigeria.

The remaining part of this paper is organized as follows: Following the introductory section is the review of relevant literature and hypotheses development. The next section describes the data and the research methodology used in the study. Finally, the last section summarizes the main findings and conclusion of the study.

\section{Literature Review and Hypothesis Development}

Dividend payout decision is the primary element of corporate policy and has been viewed as an issue of concentration in the financial literature. Since the seminal work on dividend irrelevance by Miller and Modigliani (1961), a number of assumptions have been put forward to elucidate their postulations of perfect capital markets. One crucial assumption that has been widely examined in the literature and has received 
evidence is the agency theory. The theory suggests that large shareholders' ownership may either alleviate or exacerbate agency conflicts. Thus, a high level of managerial ownership could minimize agency problems, as managers have to bear a portion of the losses arising from their divergent behaviour (Morck et al. 1988). According to Jensen's (1986) agency theory, dividend policy decisions is determined by agency costs arising from the divergence of ownership and control. Based on this cost, managers may not always accept a dividend policy that is value-maximizing for shareholders. Rather, they may adopt a dividend decision that maximizes their own personal benefits. Besides, the theory suggests that managers will rather cut or reduce dividend payouts since paying dividends reduces the amount of cash at the managers' disposal.

The concept of corporate governance according to Laporta et al (2000) is described as a set of mechanism through which outside investors protect themselves against expropriation by the insiders. In other words it is seen as a system or an arrangement that comprises of a wide range of practices (accounting standards, rules concerning financial disclosure, executive compensation, size and composition of corporate boards) and institutions that protect the interest of corporation's owners. The concept basically exists to serve as checks and balances between shareholders and management and thus to lessen agency challenges. Therefore, an effective governance framework reduces the control right conferred on managers and increases the chances that manager's investment decisions enhance the maximization of shareholders wealth (Shleifer and Vishny, 1997). Therefore, firms with better corporate governance quality incur less agency conflicts.

Prior literatures with the agency framework have examined comprehensively the association between corporate governance mechanism and dividend policy in the developed markets. Some of these studies include the works of (La Porta, Lopez-De
Salinas, Shleifer, and Vishny, 2000; Michaely and Roberts, 2006; Renneboog and Szilagyi, 2006) were they observed that a strong corporate governance framework is related to a higher dividend payouts decisions. On the other hand, prior studies by (Jo and Pan, 2009; Nielsen, 2006; Jiraporn and Ning, 2006) finds a negative relationship between corporate governance mechanism and dividend payout policy of firms in the developed economies.

More so, Short et al. (2002) examined the relationship between ownership structures and dividend policy for the UK companies. Findings from their study consistently produced a strong support that a positive association exists between dividend payout policy and institutional ownership. Similarly, Kumar (2003) examined the relationship between ownership structure, corporate governance and firm's dividend payout policy for the period 1994-2000. Findings from the study suggested the fact that an association between ownership structure and dividend payout policy existed.

Gugler (2003) investigated the association between dividend and ownership and control structure of the firm for Austrian firms. The results from the study indicated that statecontrolled firms engaged more in dividend smoothing, while family-controlled firms do not. Similarly, Wei et al. (2003) examined the association between dividend payout policy and ownership structure using 3994 observations of Chinese listed firms. They observed that there was a significantly positive relationship between the state ownership and cash dividends. However, a significant negative relationship was observed between the public ownership and stock dividends. In contrast, the findings provided in Gugler and Yutoglu (2003) showed that firms with high ownership concentration tend to pay lower dividends. Also, Maury and Pajuste (2002) found a significant negative relationship between concentrated institutional ownership and dividend payments among Finland companies. 
Also, Belden et al (2005) in a related study concluded that the greater the size of board membership, the higher is the dividends paid to shareholders. They opined that this was because there were more people monitoring the decisions made by the chief executive officer. In addition, they argued that the outside directors on the company board tend to reduce the agency cost in the firm and also represent the shareholders effectively and ensure their rights in the company. As a result, they concluded that the more outside members there were on the board, the more dividends the company was willing to pay.

Besides, Borokhovich et al., (2005) conducted a similar research on 192 US firms in the period 1992-1999 and also found out that the number of outside directors on the board led to low dividends paid out during the period examined. In addition, Khan (2006) investigated the association between dividends and ownership structure for a panel of 330 UK firms. Findings from the study indicated that a significant negative association existed between dividends and ownership structure. The study argued that ownership composition also matters with a positive relationship observed for shareholding by insurance companies. More so, in line with the other studies, Al-Najjar and Hussainey (2009) observed that outside directorship in a board has a significant negative influence on the dividends paid out because firms with higher number of outside directors on the board are more restricted to pay higher dividends.

Furthermore, Ramli (2010) also examined the effect of large shareholders and dividend policy of Malaysian companies using panel data from 2002 to 2006 . Findings from the study showed that companies made higher dividend payout as the shareholding of the largest shareholder increase.

Although existing prior literatures under the agency framework have yielded mixed evidence; several prior empirical studies from developed economies has extensively examined the direct link between some corporate governance mechanism and its impact on firms' dividend payout policy. However, the same is not true in developing economies like Nigeria. Thus, this study therefore attempts to fill this gap in literature by examining the relationship between corporate governance mechanism and the dividend payout policies of firms in Nigeria.

\section{Development of Hypotheses}

In order to examine the link between corporate governance mechanism and firms dividend payout policies in Nigeria, the following hypotheses stated in the null form were tested in this study:

H01: There is no significant relationship between the board size and dividend payout policies of listed firms in Nigeria.

H02: There is no significant relationship between ownership structure and the dividend payout policies of listed firms in Nigeria.

H03: There is no significant relationship between CEO duality and the dividend payout policies of listed firms in Nigeria.

H04: There is no significant relationship between board independence and the dividend payout policies of listed firms in Nigeria

\section{Research Methodology}

The population of interest in this study comprised of all 244 firms listed on the floor of the Nigerian Stock Exchange as at 31 December 2011. However, the study made use of a selected sample of 50 listed firms (constituting a percentage of about $20.49 \%$ of the total population) whose dividend payout policy operations has to some extent been consistent in the period under consideration. The sample size chosen is in line with the suggestion of Kerjice and Morgan (1970) that a minimum of $5 \%$ of a defined population is considered as an adequate sample size required for generalization. The judgmental sampling 
technique which is a non probabilistic sampling technique was used in selecting the sampled firms based on the availability of the financial reports for the period under review. The study made use of secondary data contained in the annual reports of the selected firms. This is due to the fact that firms' corporate annual reports remain as one of the main corporate documentary sources widely used as the communication media for conveying corporate activities to stakeholders. However, in order to effectively manage the number of observation in this study, the data obtained for each of the identified variables under review were averaged for the period 2006-2011 for each of the sampled firms. The annual reports for these periods were used based on the increased level accessibility by users during these periods. Nevertheless, in order to examine the research hypotheses stated in this study, the ordinary least square (OLS) data estimation method was used.

\section{Model Specification}

In line with the postulations as stated in the hypotheses, the following model is used to re-examine the association between the independent and the dependent variables of the listed firms in Nigeria.

$$
\begin{aligned}
& D P O_{i t}=f\left(B S I Z E_{i t}, \quad \text { OWNST }_{i t}\right. \text {, } \\
& \text { CEODUAL } \text { CH, }_{\text {BIND }} \text { Bt, FSIZE }
\end{aligned}
$$

This can be written in explicit form as:

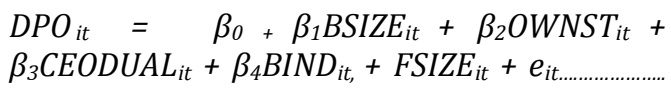
(2)

Where:

$\mathrm{DPO}_{\text {it }}=$ Dividend Payout ratio is measured as the dividend per equity share divided by earnings per share

BSIZE $_{i t}=\quad$ Firms size is proxied as total number of directors present in the Board of Directors
OWNST $_{i t} \quad=\quad$ Ownership structure has been calculated by the percentage of shares held by board of directors divided by total numbers of shares

CEODUAL $_{\text {it }}=$ CEO duality; 1 if Chairman is the CEO and 0 if chairman is not the CEO

BIND $_{i t}=$ Board independence is measured as the proportion on non-executive directors on the board.

FSIZE $_{\text {it }}=\quad$ Firms size which the control variable in this model is measured by the natural logarithm of the book value of the firms Total Assets (Control Variable)

$\begin{array}{lll}\begin{array}{l}\text { e } \\ \text { term. }\end{array} & \text { Stochastic or disturbance } \\ \begin{array}{l}\text { Variables } \\ \beta_{0}\end{array} & \text { Time dimension of the } \\ B_{1-4}= & \text { Constant or Intercept. } \\ \text { or the Coefficients of slope parameters. }\end{array}$

The expected signs of the coefficients (a priori expectations) are such that $\beta_{1}, \beta_{2}, \beta_{3,} \beta_{4}>0$.

\section{Discussion of Findings}

Results from our descriptive statistics as shown in table 1 present a mean dividend payout of about .4332 for the selected firms under consideration. This represents an average percentage distribution of about 43\%. Correspondingly; board size (BSIZE), ownership structure (OWNST), CEO duality (CEODUAL) and board independence (BIND) maintains an averaged mean distribution value of about $10.0604, .3672, .04$ and .4224; respectively for the sampled firms. This results indicate an average board size of about 10 persons which is about two third of the maximum 15 member board as specified in the Securities and Exchange Commissions' Code of Corporate Governance of 2003. Similarly, while the mean value for CEO 
duality shows that about $4 \%$ of the sampled firms have the same individuals functioning as the Chairman and the CEO; the mean score for board independence indicates that there are a lesser proportion of non executive directors (42.2\%) than executive directors on the boards of the firms.

However, findings from the correlation analysis as depicted in table 2 indicate that there is a positive association between board size and dividend payout for the sampled firms and it is significant at $1 \%$ probability level with a correlation coefficient (r) of about 0.6286 . In the same vein, ownership structure, CEO duality and board independence have a significant positive association with the dividend payout policies of the sampled firms. This is evident in there correlation coefficient $(\mathrm{r})$ values of 0.7170 , 0.2893, and 0.6178; respectively. Interestingly, firm size which depicts the control variable in this study also has a significant positive association with the dividend payout policies of the sampled firms.

Also, the study conducted a multicollinearity test before analysing the regression model. According to Field (2000), this test is necessary because multicollinearity can affect the parameters of a regression model. Adeyemi and Fagbemi (2010) suggested that a tolerance value less than 0.1 indicates a serious multi-colinearity problem between the explanatory variables, Thus, guided by this rule of thumb as an indicator of multicollinearity problems, the non-existence of multicollinearity between the independent variables was confirmed by computing the variance inflation factors (VIFs) for each of the explanatory variables which presented a mean VIF value of about 1.98 as depicted in table 5. Hence, the VIF coefficient and the residual statistics confirm the lack of co linearity and therefore sustained the model.

Findings from the regression result for the selected firms as depicted in table 4 suggest that the model is capable of explaining about $77 \%$ of the variability of firms' dividend payout. This outcome suggests clearly that simultaneously the explanatory variables are significantly associated with the dependent variable. In addition, empirical evidence in this study is consistent with our initially stated a priori expectations (i.e. b1, b2, b3, b4 $>0$ ). For the first hypothesis, a significant positive relationship was found between board size and dividend payout policies of the sampled firms. This is evident in the probability and $t$-statistics values of $(P>|t|=$ 0.001 and 3.73); suggesting a rejection of the null hypothesis. This result implies that a larger board that is functional will lead to higher dividend payouts if different board members appeal different clientele. Besides, large boards with diverse knowledge are more effective and likely to have a higher degree of independence and expertise than smaller boards in ensuring a balance in organizational dividend decisions. This outcome is however corroborates the findings provided in Belden et al (2005), Chen et al., (2011) and Bokpin, (2011) were they observed that the greater the size of board membership, the higher the dividends paid to shareholders.

Also consistent with a priori expectation, findings provided in table (4) show that there is a significant positive relationship between ownership structure and the dividend payout policies of the sampled firms in Nigeria. This is evident in the probability and $t$-statistics values of $((P>|t|=0.014$ and 2.57). This result suggests that the ownership structure of a firm has a direct impact on the dividend payouts policy of the sampled firms. That is, firms with larger distribution of shareholders tend to have more significant influence on the corporate actions that are dependent on shareholder voting. Also, majority control provides larger shareholders with considerable power and discretion over key decisions, like dividends' decisions and payout ratios. Moreover, due to the active monitoring of shareholders, managers are better aligned towards the objective of delivering shareholder value. This result is in line with the propositions of (Ramil, 2010; Gugler, 2003; Gugler and 
Yurtoglu, 2003). They argued that the dividend payouts of firms' increased as the shareholding of shareholder increased. However, it contradicts the propositions of Borokhovich et al., (2005).

Similarly, empirical findings provided in table (4) also suggest that there is a significant positive relationship between CEO duality and the dividend payout policies of the sampled firms in Nigeria. This implies that the probability of paying dividend is higher in firms where the CEO and chairman hold the same position. This outcome however, contradicts the propositions of Baliga et al. (1996) and Tsui et al. (2001) who argued that situations where the CEO is not the chairman of the board, there is a high tendency for more effective control mechanism than when the CEO is also the chairman of the board.

Finally, in addition to the aforementioned findings, table (4) also provides the result on the relationship between board independence and the dividend payouts decisions of listed firms. The regression result shows that there is a significant positive relationship between the board independence and the dividend payouts decisions of listed firms in Nigeria. This is nonetheless evident in the probability and tstatistics values of $(P>|t|=0.007$ and 2.85). This result suggest that the greater the proportion of independent directors present in the board, the higher they will be willing to pay more dividend since independent directors are monitoring investor interest by participating in the board's decisions. This outcome is consistent with the findings of Belden (2005), Kowalewski et al. (2007) and Jiraporn et al. (2008) where they maintained the fact that outside directors on the company board tend to reduce the agency cost in the firm and also they basically tend to represent the shareholders effectively and ensure their rights in the company. As a result, the more outside members that are on the board, the more dividends the company was willing to pay.

Table 1: Descriptive Statistics of Variables

\begin{tabular}{|lclllc|}
\hline Variables & Observations & Mean & Std. Dev & Min. & Max \\
\hline DPO & 50 & .4332 & .2756916 & .11 & .89 \\
\hline BSIZE & 50 & 10.0604 & 2.805157 & 4.14 & 18.29 \\
\hline OWNST & 50 & .3672 & 2513883 & .03 & .87 \\
\hline CEODUAL & 50 & .04 & .1979487 & .14 & 1 \\
\hline BIND & 50 & .4224 & .1820693 & .11 & 19.52 \\
\hline FSIZE & 50 & 4.9074 & 6.433615 & & .8 \\
\hline
\end{tabular}

Table 2: Pearson Correlations Coefficients for Sampled firms

\begin{tabular}{|c|c|c|c|c|c|c|}
\hline & DPO & BSIZE & OWNST & CEODUAL & BIND & FSIZE \\
\hline DPO & 1.0000 & & & & & \\
\hline BSIZE & 0.6286 & 1.0000 & & & & \\
\hline & 0.0000 & & & & & \\
\hline OWNST & 0.7170 & 0.3208 & 1.0000 & & & \\
\hline
\end{tabular}




\begin{tabular}{|c|c|c|c|c|c|}
\hline & 0.0000 & 0.0231 & & & \\
\hline CEODUAL & 0.28930 .1532 & 0.0761 & 1.0000 & & \\
\hline & 0.0416 & 0.2881 & 0.5993 & & \\
\hline \multirow[t]{2}{*}{ BIND } & 0.6178 & 0.3508 & 0.6107 & -0.0820 & 1.0000 \\
\hline & 0.0000 & 0.0125 & 0.0000 & 0.5713 & \\
\hline \multirow[t]{2}{*}{ FSIZE } & 0.6981 & 0.4609 & 0.6351 & 0.4481 & 0.2920 \\
\hline & $1.0000^{0.0000}$ & 0.0008 & 0.0000 & 0.0011 & 0.0396 \\
\hline
\end{tabular}

Table 3: Anova

\begin{tabular}{|llll|}
\hline Source & SS & df & MS \\
\hline Model & 2.88601245 & 4 & .57720249 \\
\hline Residual & $\mathbf{. 8 3 8 2 7 5 5 1 2}$ & 45 & .019051716 \\
\hline Total & $\mathbf{3 . 7 2 4 2 8 7 9 6}$ & 49 & .076005877 \\
\hline
\end{tabular}

Table 4: Regression Result

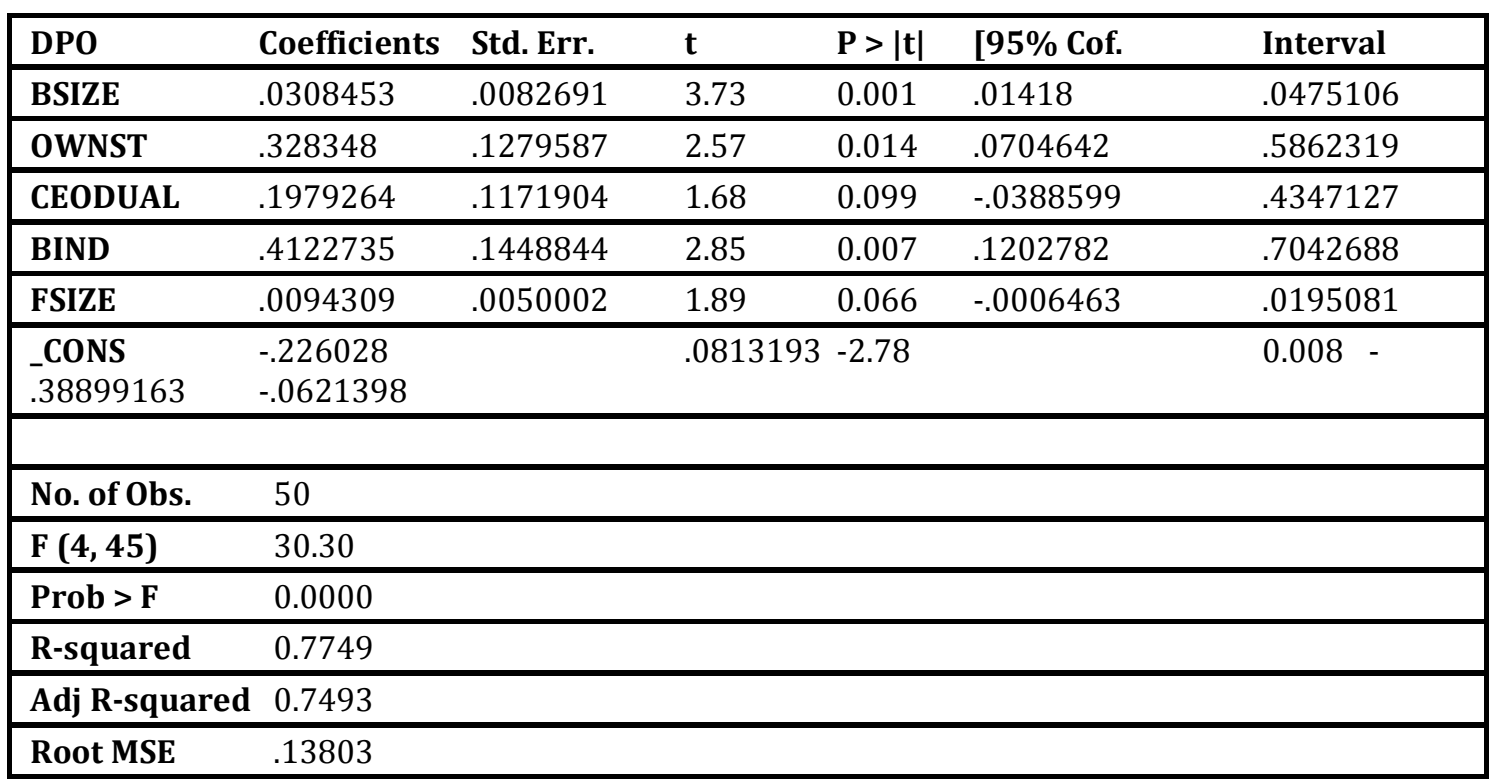

Table 5: Variance Inflation Factor

\begin{tabular}{|lll|}
\hline Variables & VIF & $\mathbf{1}$ /VIF \\
\hline FSIZE & 2.66 & 0.375712 \\
\hline OWNST & 2.66 & 0.375758 \\
\hline BIND & 1.79 & 0.558755 \\
\hline CEODUAL & 1.39 & 0.718834 \\
\hline
\end{tabular}




\begin{tabular}{|lll|}
\hline BSIZE & 1.38 & 0.722610 \\
\hline Mean VIF & 1.98 & \\
\hline
\end{tabular}

\section{Conclusion}

This study examined the relationship between corporate governance mechanism and the dividend payout policies of firms' in Nigeria. However, based on the hypotheses tested, findings from the study provided evidence to support the arguments that a significant positive relationship exists between corporate governance variables and firms dividend payouts decisions. The study observed that board size had a significant positive impact on the dividend payout policies of the sampled firms in Nigeria. Similarly, the study also observed that CEO duality and board independence have significant impact on the dividend payout policies of the sampled firms in Nigeria.

Interestingly, ownership structure also had a significant positive effect on the dividend payout policies of the sampled firms'. Suggesting that decisions on dividend payouts is likely to reduce agency conflicts by reducing the amount of free cash flow, which could be used by managers for their private benefits rather than for maximizing shareholders' wealth. Consequently, this paper concludes that greater proportion of independent directors (board independence) provides a positive influence on firms' dividend payout decisions with a view to reducing free cash flow. Furthermore, guided by the findings provided in this study, the paper concludes that dividend announcement gains more importance in firms with functional large boards with more diversified portfolio of directors. More so, they tend to serve as an effective monitoring tool to keep the management under their control and to avoid misuse of cash.

An important limitation to this study is the period for which the data is sampled. The sample horizon for this study is short compared to other samples in the literature.
To address this limitation, future research can increase the sample size.

\section{References}

1. Adeyemi, S.B. and Fagbemi, T.O. (2010), 'Audit Quality, Corporate Governance and Firm Characteristics in Nigeria', International Journal of Business and Management, 5(5), 169-179

2. Alii, K.L., Khan, A.Q. and Ramirez, G.G. (1993), 'Determinants of Corporate Dividend Policy: A Factorial Analysis', Financial Review, $28,523-47$

3. Al-Malkawi, H. (2007) 'Determinants of Corporate Dividend Policy in Jordan: An Application of the Tobit Model', Journal of Economic and Administrative Sciences, 23 (2), 44-70.

4. Baliga, B., Moyer, $\mathrm{R}$ and Ramesh, $\mathrm{P}$. (1996), 'CEO duality and Firm Performance: What's the Fuss?' Strategic Management Journal, 17, 41-53.

5. Black, F. (1976) 'The Dividend Puzzle', Journal of Portfolio Management, 2, 5-8.

6. Bleden, S., Fister, T and Knapp, B. (2005), 'Dividends and Directors: Do Outsiders Reduce Agency Costs?' Business and Society Review, vol. 110, no. 2, 171-180.

7. Bleden, S., Fister, T. and Knapp, B. (2005), 'Dividends and Directors: Do Outsiders Reduce Agency Costs?' Business and Society Review, 110 (2), 171-180

8. Bokpin, G.A. (2011) 'Ownership Structure, Corporate Governance and Dividend Performance on the Ghana Stock Exchange', Journal of Applied Accounting Research, 12(1), 61-73. 
9. Borokhovich, K., Brunarski, K., Harman, Y. and Kehr, J. (2005), Dividends, Corporate Monitors and Agency Costs,' The Financial Review, 40, 37-65.

10. Brealey, R. and Myers, S. (2005) Principles of Corporate Finance, McGrawHill, London

11. Chen, L., Lin, C and Yong-Cheol, K. (2011), 'Financial Characteristics, Corporate Governance and the Propensity to Pay Cash Dividends of Chinese Listed Companies,' International Business and Management, 3(1), 176-188.

12. Field, A. (2000) Discovering statistics: Using SPSS for Windows, Sage Publications, London

13. Gugler, K. (2003), 'Corporate Governance, Dividend Payout Policy and the Interrelation between Dividends, Research \& Development and Capital Investment,' Journal of Banking and Finance, 27(7), 12971321.

14. Gugler, K. and Yurtoglu, B. (2003), 'Corporate Governance and Dividend Payout Policy in Germany,' European Economic Review, 47, 731-758

15. Jensen, M. (1986) 'Agency Costs of Free Cash Flow, Corporate Finance and Takeovers,' American Economics Review, 76(2), 323-339.

16. Jiraporn, P., Kim, Y.S., Davidson, W. N and Singh, M. (2006), 'Corporate Governance, Shareholder Rights and Firm Diversification: An Empirical Analysis,' Journal of Banking and Finance, 30, 947-963.

17. Jiraporn, P., Kim J. and Kim, Y. (2008), 'Dividend Policy and Corporate Governance Quality', Working Paper, Pennsylvania State University

18. Jo, H., and C. Pan, (2009), 'Why are Firms with entrenched Managers more likely to Pay
Dividends?' Review of Accounting and Finance, 8, 87-116.

19. Khan, T. (2006), 'Company Dividends and Ownership Structure: Evidence from UK Panel Data,' The Economic Journal, 116, 172189.

20. Kowalewski, O., Stetsyuk, I. and Talavera. (2007), 'Corporate Governance and Dividend Policy in Poland,' Working Paper. German Institute for Economic Research

21. Krejcie, R. V and Morgan, D. W. (1970), 'Determining Sample Size for Research Activities,' Educational and Psychological Measurement, 30, 607-610.

22. Kumar, J. (2003), 'Corporate Governance and Dividend Payout in India,' Journal of Emerging Market Finance, 5(1), 15-58

23. La Porta, R., Lopez-de-Silanes, F., Shleifer, A., and Vishny, R., (2000), 'Agency Problems and Dividend Policy around the World,' Journal of Finance, 55, 1-33.

24. Lintner, J., (1956), 'Distribution of Incomes of Corporations among Dividends, Retained Earnings and Taxes,' The American Economic Review, May, 46(2): 97 - 113.

25. Maury, C. B. and Anete, P. (2002), 'Controlling Shareholders, Agency Problems, and Dividend Policy in Finland', Working Paper, Stockholm School of Business

26. Michealy, R and Roberts, M.R (2006), 'The Dividend Policies of Private Firms: Insights into Smoothing, Agency Costs, and Information Asymmetry,' working paper.

27. Miller, M. H. and Myron, S. S. (1982), 'Dividend and Taxes: Some Empirical Evidence,' The Journal of Political Economy, 90 (6), 1118-1141.

28. Miller, M. and Modigliani, F. (1961), 'Dividend Policy, Growth, and the Valuation of Shares,' Journal of Business, 34, 411-433. 
29. Morck, R., A. Shleifer and Vishny, R. W. (1988), 'Management Ownership and Market Valuation: An Empirical Analysis,' Journal of Financial Economics, 20, 293-315.

30. Nielsen, A.E.B, (2006), 'Corporate Governance, Leverage, and Dividend Policy,' Working paper, Princeton University

31. Ramli, N. M. (2010), 'Ownership Structure and Dividend Policy: Evidence from Malaysian Companies,' International Review of Business Research Papers, 6(1), 170-180.

32. Renneboog, L., and Szilagyi, P. G., (2006), 'How relevant is dividend policy under low shareholder protection?' [Online] Center Discussion Paper [Retrieved September 15, 2013],

http://papers.ssrn.com/sol3/papers.cfm?abs tract_id=925190

33. Ross, SA, Westerfield, R. W. and Jaffe, J. F. (2009) Corporate Finance Fundamentals, McGraw Hill, London

34. Shleifer, A and Vishny, R. (1986), 'Large Shareholders and Corporate Control,' Journal of Political Economy, 94, 461- 488

35. Short, H., Zhang, H., and Keasey, K. (2002), 'The Link between Dividend Policy and Institutional Ownership,' Journal of Corporate Finance, 8, 105-122.

36. Tsui J, Jaggi B, Gull, F. (2001), 'CEO domination, Growth Opportunities, and their Impact on Audit Fees,' Journal of Accounting and Audit Finance, 16,189-208

37. Uwuigbe, 0. (2013), 'Determinants of Dividend Policy: A Study of Selected Listed Firms in Nigeria,' Manager 16, 107-119.

38. Uwuigbe, U., Jimoh, J and Anijesushola, A. (2012), 'Dividend Policy and Firm Performance: A Study of Listed Firms in Nigeria,' Accounting and Management Information Systems, 11(3), 442-454

39. Uwuigbe, U (2013), 'An Examination of the effects of Ownership Structure and Financial Leverage on the Dividend Policies of listed firms in Nigeria,' Journal of Economics, Business, and Accountancy Ventura, Vol. 16 (2), 251 - 258

40. Wei, G., Zhang, W. and Xiao, J. Z. (2003). 'Dividends Policy and Ownership Structure in China,' EFMA 2004 Basel Meetings, [Online] Retrieved August 30, 2013], http://papers.ssrn.com. 